\title{
BOLONJSKA PRENOVA ŠTUDIJSKIH PROGRAMOV NA ODDELKU ZA GEOGRAFIJO
}

Bolonjska prenova študijskih programov se je na Oddelku za geografijo Filozofske fakultete Univerze v Ljubljani s prvimi pripravami začela že v letu 2004. Ravno naš oddelek je bil prvi na Filozofski fakulteti, ki je še v času predstojništva dr. Metke Špes začel z razmišljanji o bodoči strukturi študijskih programov po novih, 'bolonjskih pravilih'. Predlog študijskega programa po sistemu $3+2$, ki smo ga predstavili tudi drugim oddelkom na Filozofski fakulteti že v letu 2004, je postal nekakšen 'model' za kasnejšo prenovo na celotni fakulteti. Začetno navdušenje za bolonjsko prenovo pa se je kmalu ohladilo. Izkazalo se je, da je prenova na državni, verjetno pa tudi na evropski ravni, zelo slabo pripravljena in zastavljena. Izvajalci prenove, to se pravi posamezne univerze, fakultete in oddelki, od Ministrstva za visoko šolstvo in od drugih pristojnih institucij nismo dobili jasnih navodil oziroma priporočil, kako sestaviti nove študijske programe. Še več, pogosto je prihajalo do nasprotujočih si interpretacij Bolonjske deklaracije oziroma do sprememb v navodilih in priporočilih. Najbolj pereč je vse do lanskega leta ostal problem pedagoških študijskih programov, za katere ni bila dogovorjena osnovna struktura študija, kar je seveda onemogočalo njihovo prenovo. Običajno je bil odgovor ministrstva, da naj kar 'sami' najdemo ustrezne rešitve, ob upoštevanju specifičnosti študijskih programov. Vse to je seveda v veliki meri otežilo, predvsem pa zelo zavleklo celotno prenovo študijskih programov.

V letih 2008 in 2009 so bili po vseh opisanih težavah in z veliko truda vseh članov oddelka končno pripravljeni in akreditirani vsi novi študijski programi na Oddelku za geografijo. Po tehtnem premisleku, ob upoštevanju bolonjskega sistema študija, specifičnosti študija geografije in ciljev ter kadrovskih potencialov na oddelku, smo pripravili štiri študijske programe, ki nadomeščajo dosedanji univerzitetni študijski program Geografija: Univerzitetni prvostopenjski študijski program Geografija, Magistrski študijski program Geografija, Univerzitetni prvostopenjski dvodisciplinarni študijski program Geografija in Magistrski pedagoški dvopredmetni študijski program Geografija. Na tretji stopnji (doktorski študij) je geografija kot ena izmed številnih študijskih področij vključena v Interdisciplinarni doktorski študijski program Humanistika in družboslovje. Glede na strukturo in trajanje posameznih študijskih programov lahko ugotovimo, da prvostopenjski in magistrski študijski program skupaj $(3+2)$ v grobem ustrezata dosedanjemu univerzitetnemu študiju geografije. To potrjuje tudi (za nekatere sporna) odločitev vlade, da dosedanjo univerzitetno diplomo izenači z novim ‘bolonjskim' magisterijem ter možnostjo direktnega vpisa na bolonjski doktorski študij za dosedanje univerzitetne diplomante. V nadaljevanju bodo na kratko predstavljeni posamezni študijski programi.

Univerzitetni prvostopenjski študijski program Geografija torej delno 'nadomešča' prejšnji univerzitetni enopredmetni študij geografije. Temeljni cilj programa je posredovati temeljna znanja s področja geografije ter strokovni pogled na stanje in razvoj sodobnega sveta. Študenti naj bi v prvostopenjskem študiju pridobili predvsem kvalitetno osnovno geografsko izobrazbo za kasnejše uspešno nadaljevanje študija in specializacijo v posamezna področja geografije. Posebna pozornost je namenjena temeljnim občegeografskim predmetom, ki so deloma združeni v predmete Fizična geografija I in II ter Družbena geografija I in II, 
ter študiju geografskih specifičnosti Slovenije, predvsem vzrokom in posledicam velike pokrajinske pestrosti. V času študija študenti osvojijo osnovno filozofijo stroke ter tudi mednarodno primerljive metode geografskega preučevanja, predvsem pa obvladajo analizo in temeljno vrednotenje pokrajine, njenih sestavnih delov in razvojnih dejavnikov. Študijski program omogoča tudi določeno izbirnost med geografskimi, regionalnogeografskimi in 'zunanjimi’ strokovnimi predmeti. Ker bo zaposljivosti diplomantov prve stopnje študija geografije verjetno precej omejena, pričakujemo, da bo večina študentov nadaljevala študij na drugi stopnji.

Magistrski študijski program Geografija tako predstavlja teoretsko, metodološko in vsebinsko nadaljevanje študijskega programa prve stopnje. Osnovni poudarek študijskega programa je specializacija, kar se odraža v izbirnosti med petimi študijskimi smermi (t.i. moduli). Pri tem smo obdržali dosedanje uspešno uveljavljene geografske usmeritve in dodali nekaj novih. Na ta način smo oblikovali pet študijski smeri. Pri tem ločimo dve obsežnejši, tako imenovani A študijski smeri (okoljska in fizična geografija ter regionalno planiranje in urbano-ruralne študije) in tri B študijske smeri (politična geografija, geografija turizma in uporabna geoinformatika). Študent izbere eno izmed A in eno izmed B študijskih smeri. Za vse študente drugostopenjskega študija je obvezna 15-dnevna delovna praksa in terensko delo, ki je vezano na vsebino izbrane študijske smeri. Študij se zaključi z zagovorom magistrskega dela, ki je problemsko in vsebinsko vezano na eno od izbranih študijskih smeri. Študijski programi predmetov so neposreden odziv na najnovejša dognanja v naši stroki, obenem pa tudi na potrebe prenosa teh znanj $\mathrm{v}$ prakso, na področja, kjer so potencialne možnosti za delo v raziskovalnih ustanovah, na delovnih mestih v upravnih institucijah na državni in lokalni ravni, v turizmu, novinarstvu, pri reševanju okoljevarstvenih problemov, načrtovanju sonaravnega razvoja in preprečevanja negativnih učinkov naravnih nesreč, v planerskih institucijah, v urbanizmu, urejanju podeželja, urejanju medetničnih odnosov in vprašanj Slovencev po svetu, v vladnih službah, privatnih agencijah, pri pripravi prostorskih informacijskih sistemov ter avtomatizirane tematske kartografije itd.

Magistrski študijski program je zasnovan interdisciplinarno, predvideno je povezovanje s številnimi sorodnimi strokami, na primer prostorska sociologija, urbana in regionalna ekonomika, krajinska arhitektura, urbanizem, ruralno planiranje in varstvo okolja. Tako zasnovan program omogoča široko zaposljivost na že uveljavljenih področjih zaposlovanja geografov: prostorsko in urbanistično planiranje, regionalni razvoj, razvoj podeželja, varstvo okolja, turizem, mednarodne integracije, manjšinska politika, geoinformatika in druga.

Univerzitetni prvostopenjski dvodisciplinarni študijski program Geografija je rezultat skupnega dogovora na Filozofski fakulteti o preoblikovanju in vključevanju dosedanjega dvopredmetnega in pedagoškega študija v nove bolonjske študijske programe. Tako imenovana 'odprta' dvopredmetnost, oziroma prosta izbira in povezovanje med vsemi strokami, je nedvomno posebnost in prednost Filozofske fakultete, ki pa jo je bilo izredno težko vključiti v nov bolonjski sistem univerzitetnega študija. Dodaten problem je predstavljala že omenjena nedorečenost trajanja in strukture pedagoških študijskih programov in s tem povezana pridobitev pedagoškega naziva, ki omogoča samostojno poučevanje. Po večletnem delu so bili v letu 2009 končno akreditirani tudi dvopredmetni in pedagoški študijski programi. Končna 'rešitev' predvideva prvostopenjske dvodisciplinarne študijske programe in peda- 
goške magistrske dvopredmetne študijske programe. Študent/ka na Filozofski fakulteti izbere izmed akreditiranih in razpisanih dvodisciplinarnih študijskih programov poljubna dva programa, ki skupaj tvorita celoto. Kot doslej, bo tudi v bolonjskih programih struktura dvodisciplinarnega študija enakovredno sestavljena iz vsebin in kompetenc dveh disciplin oz. strokovnih področij. Univerzitetni prvostopenjski dvodisciplinarni študijski program Geografija torej obsega le 90 kreditnih točk, kar je z vidika geografije izredno malo. Kljub temu upamo, da bodo študenti uspeli pridobiti znanja, ki po mednarodnih standardih veljajo za temeljna znanja s področja geografije. To jim bo omogočalo prepoznavanje in razumevanje naravnih in družbenih procesov oblikovanja in preoblikovanja Zemljinega površja ter odnosa med naravo in družbo v prostoru. Študijski program je nepedagoški, saj je tako imenovani pedagoški modul v celoti vključen v magistrski dvopredmetni študijski program.

Magistrski pedagoški dvopredmetni študijski program Geografija je torej 'logično' nadaljevanje prvostopenjskega dvodisciplinarnega programa in omogoča pridobitev pedagoškega strokovnega naziva magister profesor / magistrica profesorica geografije. Študijski program je sestavljen iz strokovnih geografskih predmetov (regionalnogeografski predmeti) in skupnega pedagoškega modula. Pedagoški modul obsega dva dela: skupni del pedagoškega modula na ravni fakultete (pedagogika, andragogika, didaktika, psihologija za učitelje) in specialni del, ki ga izvajajo posamezni študijski programi (specialna didaktika geografije). Pedagoški modul vključuje tudi pedagoško prakso. Temeljni cilj programa je izobraževanje študentov za prenos strokovnega geografskega znanja v različne vrste in oblike izobraževanja na vseh šolskih stopnjah. Diplomanti si pridobijo znanja iz dveh znanstvenih disciplin in temeljne pedagoške kompetence, s čimer so usposobljeni za poučevanje v osnovnih in srednjih šolah ter drugih izobraževalnih ustanovah.

Doktorski študij na Filozofski fakulteti je organiziran v okviru skupnega Interdisciplinarnega doktorskega študijskega programa Humanistika in družboslovje. Program sestavlja 62 znanstvenih oziroma študijskih področij, med njimi tudi študijsko področje Geografija. Program poleg Filozofske fakultete skupaj izvajajo še Fakulteta za družbene vede, Akademija za glasbo, Teološka fakulteta, Fakulteta za računalništvo in informatiko ter Fakulteta za matematiko in fiziko. Oddelek za geografijo bo sodeloval tudi na nekaterih interdisciplinarnih študijskih področjih, kot na primer Evropske študije, Balkanski študiji ter Etnični in migracijski študiji. Doktorski študij na področju Geografija je zasnovan kot poglobitev in nadgradnja magistrskega študija geografije. Njegov cilj je oblikovanje vrhunsko usposobljenih znanstvenikov raziskovalcev in pedagoških delavcev na področju geografije.

Oddelek za geografijo na Filozofski fakulteti Univerze v Ljubljani je torej uspešno zaključil bolonjsko prenovo svojih študijskih programov. Prenova je bila zahtevna in dolgotrajna, pomenila pa je tudi priložnost za prevetritev in izboljšanje študija. V naslednjih letih se bo pokazalo, če smo bili pri tem uspešni.

Dejan Rebernik 